\title{
BETWEEN LOVE AND MARRIAGE: DILEMMA OF GAY'S LOVE (A Qualitative Study of Phenomenology in Gay People)
}

\section{Gumi Langerya Rizal ${ }^{1}$}

${ }^{1}$ UniversitasNegeri Padang, Padang, Sumatera Barat, $\square$ (e-mail) gumi.langerya@gmail.com

\begin{abstract}
Being a life partner and having a family is one of the tasks of personal development in early adulthood, as well as a homosexual person or a gay person. Differences in sexual orientation and rejection in relation to the environment, family and religion, however, make the desire to get marry being a conflict in a gay person. In this study, the author highlights the phenomenon of the inner conflict between love and marriage that occurs in a gay person. The author reveals phenomenology to express the experience and psychological dynamics of a gay person who wishes to change and marry. The results showed that a person with homosexual has a great desire to change and marry. However, this desire is not a wish or a hope that is easy for a gay person to realize. Many experiences have been shared, views on his life, fears, conflicts and hopes that exist in him, which also encourage and complicate his desire to marry.
\end{abstract}

Keywords:Sexual orientation, homosexual, marriage

\section{Introduction}

The phenomenon of same-sex relationships is no longer a new phenomenon in Indonesia. Since the founding of an organization in 1987, the organization "Gaya Nusantara" is the first organization founded by homosexual (gay) and community couples intended for men who have an emotional and physical attraction to the same sex. Since the establishment of this organization is the dissemination of information and the awareness that this phenomenon is actually present in the environment. From year to year similar communities appear in almost every region of Indonesia, although there are not many communities that are still closed and have not dared to preach their fellowship to other people who are emotionally and physically interested in the same sex, how you feel. As with the story of one of the organizers of a gay organization, they said that they used the male reproductive health mission as "cover" to legally recognize the existence of their organization and be funded by the founder. 
Homosexuality according to Kendal and Hammer (1998) is sexual attraction, which is not only about sexual contact with the same sex, but also about people who have psychological, emotional and social interests towards someone of the same sex. Similarly gay is a man or woman who has physical, emotional, and mental attraction to someone of the same sex (Gamache and Lazear, 2009). However, in Indonesia the term gay is widely used for men who have an interest in men, while women who have an interest in fellow women are called lesbians. Although today homosexuals are no longer classified as a psychiatric disorder, they have been excluded from the PPDGJ III and DSM IV books, but the influence of social, religious and environmental norms has made homosexual sexual orientation not well received in the environment. Indonesian people still consider that homosexual sexual orientation is a disorder so people who are believed to have this disorder tend to be treated differently and seen as something unnatural and bad.

Environmental, cultural and religious issues are some of the reasons why people who have homosexual sexual orientation do not dare to acknowledge and show their situation to others outside their community. This is in accordance with the opinion (2003) which says that the threat of religion and the social environment causes gays to be afraid of negative treatment and harassment from the community, thus preventing gays from showing their sexual orientation and opening themselves up (coming out).

Coming out according to Hyde (in Rahardjo, 2007) is a gay person who has been able to show his sexual orientation and identity to others. Whereas the term that contradicts coming out is "in the closet" which is used for gays who also live a life like someone who is heterosexual namely by marrying, having children, and socializing with other people.

Based on the results of informal interviews with researchers on a gay person. The informant said that:

"Aku enggak berani untuk kasih tau kepada orangtua dan keluarga. aku gamau mereka menganganggap aku salah, berdosa, dan aneh. Mereka pasti kecewa. kalo mereka tahu mungkin aku bisa diusir dan gak jadi anak mereka lagi dan pastinya aku ga mau."

The statement above shows that the family as the area of the nearest environment influences the courage of a gay person to honestly open himself (coming out) to others.

The decision to come out or not will certainly put pressure on a gay person, especially the demands of the family for a gay who has reached adulthood, namely the demand for marriage. These demands can be a concern for a gay person. As the results of a field study conducted by Maning (2010) show that there is concern for some gays that he will be forced to marry women by his parents. This concern was caused by other gay experiences who were forced to marry but did not get the happiness from the marriage. This experience made some gays worry so they decided they would never marry if not with the man he loved. In addition to demands from the family, the desire to get married can also be owned by a gay person. Having a family and biological child is a desire that usually appears in people of adulthood. According to Havighurtst (in Hurlock, 2002) the task of developing some early adulthood is to build intimate relationships, choose a life partner, and start building a family. Likewise, a gay person at that time will also have the same developmental task, but differences in sexual orientation and rejection factors from the environment, family, and religion make the desire to get married become a conflict in a gay person. This situation makes some gays unable to accept his condition so that it becomes a burden for him. An informant said that:

"Terkadang aku ngerasa kenapa tuhan membuat aku berbeda dari yang lain. Aku tidak bisa seperti yang lainnya. Harusnya bergaulnya aku tidak seperti ini. nantinya aku ingin menikah meskipun bukan dalam 
waktu yang dekat. Tapi aku ingin menikah. aku harus bisa seperti yang lain. Punya keluarga dan anak. Tapi terus terang aja, aku bingung dan takut."

Cultural factors and state laws cause the desire to marry happily owned by a gay person to be difficult. The environment makes a gay person unable to get what he wants. This internal conflict felt by gays makes a gay person must choose to prioritize his happiness or normative views from the environment. Not a few gay people have the desire to be "normal" so that they can be accepted in society but not a few gay people who have difficulty changing their orientation and interest so that they can like someone with a different sex with him.

The conflict between desires in self, the task of development, ability, and environmental demands causes conflict in a gay person. The desire to marry, hope and happiness in the future of a gay makes researchers interested in researching more deeply about the phenomenon of conflict that occurs within a gay person who has the desire to marry and have the childIn addition, the lack of discussion about the conflict of desire for marriage in a gay person makes researchers feel that in-depth research related to this conflict is necessary.

\section{Method}

\section{Research Perspective}

In this study researchers also used phenomenology methods. Phenomenology is describing the meaning of a person's life experience related to a particular phenomenon (Creswell, 2003). Where through phenomenology can be produced how someone views an event or phenomenon that he experienced from his perspective. In phenomenological research there are several core processes (Moustakas, 1994) which are to eliminate the prejudices, biases, and opinions of researchers about something. Then, focus on what is studied only and each answer has the same value. Then the next process which is irrelevant or overlapping statements is omitted, grouping them into themes, arranging themes that are in accordance with the phenomenon under study so that a structured descriptive is formed. Next, integrating the description into a statement as the main point of experience of a phenomenon.

\section{Research Participants}

Participants in this study were a man of early adulthood who had a sexual orientation towards the same sex (homosexual) and had the desire to get married and wanted to change his sexual orientation.

\section{Sampling Technique}

This study uses a snowball sampling technique. This technique is used by researchers because it is difficult to get participants who want to open themselves (coming out) to people who are new to the participants. In addition, before the researchers did not have acquaintances, contacts, or information related to data sources (participants) in the city of Yogyakarta.

\section{Data Analysis and Interpretation Procedures}

Data analysis begins by describing a case that contains an introduction to participants and narratives of the phenomenon experienced by participants since he was small so far that has a connection with homosexual phenomena in the participants. After the description of the case it is followed by a phenomenological analysis carried out by revealing the themes that exist in the subject phenomenon based on the results of interviews that have been conducted. Furthermore, the authors compile the psychological dynamics of the participants by re-explaining the life journey of participants based on the description of the cases that have been described, themes that have been found in phenomenological analysis, literature references, and from the author's interpretation of the results of observations and interviews to participants either directly to participants or from secondary data. 
After revealing the psychological dynamics of the participants, the overall analysis was carried out which contained a diagnostic description of the subject and the stages of the case development of the participants in accordance with the literature.

The interview process is carried out casually but leads to a specific goal. The research process begins with building rapport with the aim that participants can trust the researcher so that they can express all what happened to the participants honestly and truthfully. During the interview the data obtained is always recorded. Researchers recorded informations ininterview transcripts and field notes. The transcript contains all the results of interviews with participants who have also been given a code that matches the contents of the conversation. While the field notes contain the results of observations and projections of the views and feelings of researchers when meeting with participants.

\section{Research Validity}

The validity of the study was carried out with intersubjective validity (Creswell, 2003), which is to re-examine the understanding of researchers with participant understanding by generating reciprocal interactions between participants and researchers. This method is carried out with the aim that the understanding conveyed by participants regarding a particular phenomenon can be raised according to the participants' understanding.

\section{Credibility}

The credibility of research data is the reliability of research data. So to increase the credibility of research data, researchers applied the steps:

1. Researchers build trust and good relationships with participants.

2. Researcher writes verbatim transcripts as accurately as possible.

3. Researcher conducted additional interviews with close friends of the participants who aimed to cross-check the findings of the research data.

\section{Results and Discussion}

\section{Case Description}

\section{Introduction to Subjects}

The first time researchers met the subject on the evening. At that time the subject was introduced by a fellow researcher. At that time the subject was gathering with his friends. When the beginning of getting acquainted the subject told me that he wanted to get married, but that night not much was told by the subject because there was a very noisy crowd so at that time the researcher only talked about the current subject's busyness and a little about the subject's education.

Currently the subject works as a Sales Promotion Boy in a shopping center in the city of Jogjakarta. The subject lives with his family in Jogja. Every day the subject activities besides working, he gathered with his community just for fun. The subject worked as SPB since he graduated from high school. The subject did not continue to study because he was tired of studying, he wanted to make money.

\section{Homosexual Case}

Based on PPDGJ (PedomanPenggolongandan Diagnosis GangguanJiwa) III, subject homosexual sexual orientation is F66.1 (egodistonic sexual orientation). According to PPDGJ III (Maslim, 2003) Egodistonic sexual orientation is

"Identitas jenis kelamin atau preferensi seksual tidak diragukan, tetapi individu mengharapkan yang lain disebabkan oleh gangguan psikologis dan perilaku, serta mencari pengobatan untuk mengubahnya" 
Based on this explanation, the subject met the egodistonic sexual orientation criteria. The subject has a great desire to change, and feels himself not normal.

"aku pengen kayak orang normal lainnya. aku sayang sama keluarga aku. Aku ga mau mereka merasa malu kalo tau aku yang kayak gini. Aku juga mau punya keturunan. Aku liat mas-mas ku itu kayaknya bahagia punya keluarga. Anak-anaknya lucu-lucu. Aku liat orangtua aku tu bahagia ngeliat cucu-cucunya. Yaa aku tu ya mau juga gitu."

"Aku ga normal kalo kayak gini terus. Aku takut juga nanti apa yang terjadi kalo aku bilang. Mangkanya aku mau berubah."

Whereas based on homosexual groupings according to Kartono (1989), subjects classified as passive homosexuals. Passive homosexuals are subjects who act as women and tend to behave feminine / sexual (transcript no 353-354).

\section{Phenomenological Analysis}

Egodistonic Homosexual Cases on the subject can be explained into several stages of the subject's life and accompanying feelings:

1. Before he realized he had a homosexual sexual orientation

1.1. Proximity to women and imitating women's behavior

Since childhood and before the subject realized he had a homosexual sexual orientation, the subject had closeness with many women. The subject is close to his mother and sister. The subject refused to play and was close to the man because according to him the game of men was rough and the games of women were funny.

"Aku sukanya main ma cewek. kayaknya mainannya itu lucu-lucu... hehehe (ketawa)."

"SD itu aku mainnya ma cewek juga. Bagi aku cowok itu jahil ya. Terus mainannya itu kasar-kasar. Jadi aku ga suka. Aku dulu juga sering diolok-olok karena aku mainnya ama perempuan aja.tapi yaaaaaa aku ga papa mbak. Paling juga nangis tyerus udah."

Besides being in school, the subject often plays with his mother, sister and cousin. The subject rarely plays with his brother. The subject often quarreled with his brother. but the subject is very happy when with his sister because he is always listened to. Since childhood, he was happy to follow what his mother and sister did at home. The subject tried to wear his mother's clothes but quietly in the room.

"Aku deketnya ma mbak ku. Aku suka curhat sama mbak ku. Dulu itukan aku cengeng ya mbak. (hihihi). Jadi kalo aku dijahilin di sekolah trus dirumah aku nangis, mas-masku malah ngeledekin. Tapi mbak ku itu yang bisa dengerin aku. Ya jadi aku sama mbak ku itu kayak sahabat. Aku suka contoh apa yang mbak dan ibukku lakuin. Mereka masak ya aku juga masak-masakan di luar sama temen-temenku. Trus mereka pake baju bungabunga cantik gitu ya aku coba-coba juga. Ya pokoknya aku tiru lah."

\subsection{Got sexual harassment by an unknown person}

Subject got sexual harassment when he was in middle school. When he was in a cinema. the subject gets abuse by someone who claims to be conducting research on the vitality of a man. At that time, the 
subject did not consider this to be harassment. After the incident he often imagined the incident and imagined having sexual relations with a man.

"iya. Tapi ya waktu pertama itu bingung tapi aku tu dulu sempat kebanyang-banyang ngelakuin "itu" ma cowok. Karena aku dulu SMP pernah di anuin.. oo apa itu namanya.. digituin lah ma cowok di bioskop. Akunya ga kenal. Dia datang terus ada alasan-alasan sesuatu lah. Penelitian juga kayak mbak. Hehehehe. Dia megang gitu. ya enak e mbak tapi akunya lari. Tapi udah itu ya kalo mbayangin gituan ya aku kebayangnya ma cowok mbak."

This story is also justified by a friend of the subject.

"Ya kejadian pertama dia berhubungan dengan cowok itu waktu di bioskop sih. Dia di gerepe-gerepe (tertawa) pas lagi nonton rame-rame di indra, tu yang dekat oyot godhong itu lo. Kan disana ada bioskopnya itu lo. Disebelahnyakan ada cowok. Tapi dia ga kenal. Pas waktu itu dia sama temen-temen SMPnya."

2. After realizing having a homosexual sexual orientation

2.1 Comfortable and feel protected by men

The subject first realized he had homosexual sexual orientation when he was in junior high. The feeling that arises when he is with a man is feeling protected so he feels comfortable. Feelings of dislike for men when they are small because he thinks that the man is mischievous turns to like it if he meets a man who has the opposite nature of the type of man he does not like.

"oooo iya... jadi waktu itukan aku kelas 2 SMP punya temen deket. Deket banget. Karena dia aku liat baik banget ma aku.. emm.. apa ya.. kita itu kalo kemana-mana sama-sama. Aku tu suka aja sama dia. Kalo deket dia itu aku nyaman. Ngerasa ada yang ngelindungi aku."

Since he felt that he had a different feeling if he met a man, he felt that he was more suited to having a lover with a man. Whereas women are more suitable as friends to confide in. The subject felt that he was not much different from women.

"Aku jadi semakin ngerasa aku itu lebih cocok ke cowok aja. Cowok itu lebih bisa bikin nyaman."

The subject has a different feeling if he meets a man.

"Aku Cuma temen untuk dia. Gitu e mbak. Yoo "jegger" rasanya mbak. Abis itu aku ketemu cowok cakep pas aku masih sedih-sedihnya.. terus aku suka. Deg-degan kalo ketemu tapi pengen deket terus kayak sama temen deketku waktu kelas 2 itu."

\subsection{Feelings for women}

After the subject realizes that he has feelings for the subject subject, he likes a woman. Because of the feeling of affection the subject stated that he liked the woman, but the woman who liked the subject only considered the subject as a friend. This makes the subject disappointed and sad (subject, transcript no 59-66). But after the incident the subject felt it was difficult to foster a sense of liking for women and thought women were only suitable to be friends.

“Waktu SMP juga. Aku suka banget ma cewek. tapi kalo aku ingat sekarang aku yoo heran kok bisa suka gitu ma dia itu. Sekarang aku mau bisa suka lagi kok ya ga bisa. Kayaknya ga menarik gitu." 
"Waktu aku ditolak itu malah aku jadi makin ngerasa aku tu emang ga cocok untuk pacaran ma cewek. cewek itu enaknya untuk jadi temen curhat aja."

\subsection{God's destiny}

The subject felt that what made him like the same sex was God (subject, transcript No. 69). Because for him since a long time ago he had had that feeling. But the subject also said that the refusal by the woman he had ever liked made him feel even more that he was not suitable for dating women (subject, transcript No. 31-32). This shows that the subject feels disappointed with the woman and feels that she is not a suitable person for women, so she chooses to continue to maintain her feelings for men, making it difficult to change her current orientation.

\subsection{Happy}

As long as he is a man who has a homosexual sexual orientation, the subject often engages in sexual activities with a man. The subject feels good and always imagines doing it with men.

"Dia megang gitu. ya enak e mbak tapi akunya lari. Tapi udah itu ya kalo mbayangin gituan ya aku kebayangnya ma cowok mbak."

Int : apa yang mas rasakan ketika menjalani kehidupan seperti saat ini?

Ite: awalnya seneng mbak. Seneng la.. enak.

\subsection{Lust}

Subject has sexual relations based on lust rather than likes. The subject feels that sexual intercourse now is a need that he must always fulfill. A very big appetite that this subject realized made the subject feel something was not normal in him. This lust also makes the subject not pick and choose who will be his "sleeping companion".

"Aku tu kan kayak gitu-gitu itu udah ga pake perasaan sayang ato cinta tapi ya Cuma karena enak aja. Apa ya itu. Nafsu ya. Ada yang minta ya udah aku kasih. Aku mau ya aku ajak orang. Ya gitu lah mbak. Jadi kayak makanan sehari-hari itu lo mbak. Kalo nggak itu rasanya ga enak. Maunya itu setiap hari ada banyak. Lebih dari sekali. Kadang juga sama beberapa orang dalam sehari. Sama yang baru aku ketemu juga oke aja."

\subsection{Fear}

Many fears that the subject feels when he has realized that he has an interest in the same sex. The subject began to realize that there was something abnormal in him so he did not dare to tell others about his situation. The subject cannot accept what others will respond to his confession so that until now the subject has not dared to say the condition of his sexual orientation, but the subject has the desire to change. The fears that arise during this time are the subject of fear that everyone will be disappointed in him, he will be ostracized, get hurt, and be shunned by his family. In addition to fears related to relationships with others, the subject is also afraid of death..

"Aku ga berani bilang mbak. Nanti semua orang kecewa sama aku. Aku masih ngerasa aku salah. Aku ga normal kalo kayak gini terus. Aku takut juga nanti apa yang terjadi kalo aku bilang." 
"kepikiran (beritahu lingkungan dan keluarga) pernah. Tapi aku ga berani. Aku ga mau juga oranglain tau. Nanti aku bisa celaka. (int :"celaka?") iya celakanya aku nanti jadi dibenci orang. Dijauhi masyarakat. Ya ga maulah mbak."

int: "yang paling mas takutkan?" ite: "kematian, dijauhkan dari keluarga, dikucilkan, terus apa lagi ya... itu dulu aja deh."

3. Have the desire to get married

Subjects have a great desire to get married and have a family. Marriage is something that the subject really expects.

"Aku juga sering banget kepikiran untuk menikah. Punya keluarga. Punya anak. Aku suka anak-anak mbak.

This great desire to get married is also justified by the subject friend.

"besar sih (keinginan menikah). Karena dia ngomong kayak gitu serius. Kalau ada temenku nikah, dia itu ya bingung sendiri. kepikiran "kok aku ini kayak gini. Kapan. dia kapan waktunya kayak gitu"

\subsection{Conflict}

The conflicts that have existed in the subject when he was asked by his mother to take his girlfriend home. The subject was confused because he could not bring his girlfriend home. The subject has closeness to his mother so the subject always tries not to disappoint his mother. But in that condition the subject cannot give what the subject mother wants. So that a conflict arises in the subject, he wants not to disappoint his mother, but he is unlikely to acknowledge and show that he likes a man.

“Cuma aku pernah ditanya kok aku ga pernah bawa pacarku ke rumah. Ibuk ku katanya pengen kenalan juga sama calon menantunya.. ya aku gimana gitu rasanya ya mbak. Aku tu kan ya ga mungkin bawa cowokku kerumah. Bisa gempar gitu deh nantinya."

Another conflict is the desire of the subject to change but the subject realizes that to change its orientation is not easy and he still cannot let go of feeling good when having a relationship with a man.

"Aku takut juga nanti apa yang terjadi kalo aku bilang. Mangkanya aku mau berubah. Walaupun susah banget ya mbak.. udah terlanjur enak e."

"Masih pengen (berubah dan menikah). Tapi belum kesampaian. Susah mbak."

The subject wants to get married because he feels there is something abnormal in him, but the absence of feelings of love or interest in the subject of women makes the subject have a conflict within him. The subject does not want him to marry if he is unable to give love to his partner later because he feels he will be very sorry and can't bear to be his wife and not get love from him.

"ya mau aja sih mbak (menikah dengan perempuan). Tapi aku ga bisa janjikan kalo aku bisa suka ato cinta ma dia." 
"Aku mau banget untuk menikah tapi aku juga ga mau, nikah tapi aku ga suka. Apa ya.. aku kasian juga nanti sama dia. Aku ga tega gitu mbak. Aku bayangin kalo ibuk ku yang aku gituin pasti sedih banget pasti ibuku. Aku mau aku bisa menikah dengan orang yang aku cintai. Tapi haduhh. Ya gimana ya mbak. Aku ga bisa lagi jatuh cinta ma cewek. kadang aku tu jadi sedih sendiri kalau liat orang nikahan. Aku pengen. Tapi aku tu mau sama siapa. Aku bisa cintanya sama cowok. Tapi ga mungkin aku nikah sama cowok. Aku juga ga mungkin punya anak dari cowok juga kan mbak. ya pokoknya aku masih pusing kadang. Jadi semakin aku pikirin itu aku jadi semakin banyak ngelakuin "itu" ke cowok-cowok."

\subsection{Hope}

The hopes for the future of the subject are to be the same as the average person who he thinks is normal from him. The subject wants to have offspring and feel happy. Besides the subject wants him to be happy, the subject also wants his parents to be happy with him marrying and having children. According to the subject of other happiness is if he is able to feel the same pleasure later if he is with women.

"aku pengen kayak orang normal lainnya. aku sayang sama keluarga aku. Aku ga mau mereka merasa malu kalo tau aku yang kayak gini. Aku juga mau punya keturunan. Aku liat mas-mas ku itu kayaknya bahagia punya keluarga. Anak-anaknya lucu-lucu. Aku liat orangtua aku tu bahagia ngeliat cucu-cucunya. Yaa aku tu ya mau juga gitu."

"bahagia mbak. Tapi mungkin bahagia untuk keluarga aku. Kalo aku sendiri aku ga yakin aku bisa bahagia ato enggak. Tapi ya aku pikir ya ga papa lah. Ibuk bapakku juga udah tua. Kapan lagi aku bisa bahagiakan mereka."

"bisa merasakan kenikmatan yang sama kalo saya nanti berhubungan dengan cewek. itu kali ya mbak. Karena aku ga mau kehilangan enaknya pacaran sama cowok itu kalo nanti aku pacarannya ama cewek. ya gitu deh mbak. Hehehehe."

\section{Psychological dynamics analysis}

The subject is the last child of four siblings. The subject is very close to his mother and tends to be spoiled. The subject has two brothers and q sister but the subject is only close to his sister. The subject felt both of his brothers likely to tease andhumiliate him. Since childhood, the subject has always been spoiled by his parents, especially his mother. Subjects rarely meet with the subject's father, so the subject is often with the subject's mother and sister. The subject is happy to imitate the activities of his mother and sister so that since childhood the subject is accustomed to playing and hanging out with women. The subject tried to follow what his mother and sister did including their clothing style, which is a female clothing, so that the subject had tried to wear dress similar to his mother and sister (subject, transcript No. 189-193).

The subject's sexual movements make the subject often bullied and teasedby his schoolmates so that the subject feels more comfortable and safe when playing with his female friends and internalizing the entire experience of women as a part of him. The negative view of the subject towards men and unpleasant treatment that often the subject found from his male friends made the subject accustomed to hanging out with women and imitating the behavior of women, besides the absence of closeness to his father and brother made the subject have no example of how he should behave like a man. Until finally the subject found a male figure who was judged by the subject to protect him. This makes the subject feel he found someone who protected him and made him amazed so that he changed his views so far towards men. This protected feeling makes the subject interested in 
the male figure but planting values and learning processes from the environment so he feels he is a person who has feelings for men like women to men.

When junior high school the subject once liked a woman but the rejection by the woman made the subject feel more and more that he was better suited to the man (subject, transcript No. 48-53). The subject felt disappointed with the woman he had attracted to men and since then the subject has never been able to be in love with women eventhough he wants to be able to like women as he likes men. As long as dealing with men the subject feels enjoys and good so that the subject feels he has a great desire for sexual relations with men. The feeling of enjoying the first time and what makes the subject always imagine sexual intercourse for the first time with a man is that after he had been touched by unknown gay person in a cinema, the subject feels an unusual enjoyment but also scared at the same time (subject, transcript No. 50-59).

The incident made the subject feel that when he was treated like that he would feel good. So that after that event the subject felt that he has an interest in men. In high school, the subject began to have a relationship with a man and joined a homosexual community. Subject felt he has the same friends as himself in the community. Since having a relationship with a man and "sexual activity" with a man, he has a need to have sexual activity every day (subject, transcript no. 67-76).

Since the subjects have to get more than oncesexual activity in a day and subject feel that what he did is not normal, and also he getting tired to do it because they must always lie and cover themselves. This feeling makes the subject wantsa change and start thinking about getting married to a woman. The subject wants to have a family and have children. The subject wanted to change because he wanted to be like other normal people and also family factors made the subject decide to try to change himself. He did not want the family to be embarrassed to learn that he had a homosexual sexual orientation. During this time the subject saw people around him as comparison, for example like his brothers whose living happily after marriage. This makes the subject feel happy when thinkingaboutgetting marriage. The subject's family never asked about marriage but his mother once had asking to see the his boyfriend which is made the subject confused and did not dare to tell her about the real situation. The subject was afraid that his whole family would disappointed and got opposed or rejected by the community.

Subject's fear pushes him to change, eventhough the subject realizes that it is very difficult. The subject wanted to get married, but he doubted whether he could love the woman he was going to marry later and he was also afraid of hurting her if he married but did not love her as a wife. But on the other hand, the subject already prepared himself if later he has to be unhappy to live innormal marriage as long as both parents are happy. Subject felt that it did not matter if he was unhappy as long as he could make his parents happy. His greatest fear is if he has to keephimself away from the family due to his homosexuality.

\section{Discussion}

Subject belonging to the ego-dystonic sexual orientation which can be defined as a homosexuals who have a desire to change. Since his childhood, subject associates with women and rarely make friends with men as well as subject since childhood rarely establish closeness with his father so that the subject loses a male figure as an example in the process of social learning in childhood While the two brothers who subjected the subject frequently made the subject keep a distance and play more and closer to his mother and sister. The closeness between the subject and the female and the rare subject to get along with men make the subject accustomed to modeling all women's behavior. In accordance with the results of Lippa's research in 2005 and Ruble \& Martin's research in 1998 (in Zheng, Lippa, \&Zheng, 2010) which showed that social learning, social rules, social stereotypes, and the influence of socialization were able to cause someone's homosexuality. 
In addition to these social factors, the absence of an amplifier for the feeling of the subject when he likes someone (the subject is rejected by the woman he likes) makes the reinforcement of his homosexual sexual orientation appear. The subject becomes disappointed with women and then gets attention from a man making the subject feel that he is only able to be accepted by men. This situation or belief is always the subject holds until finally the subject gets used to liking men and losing feelings for women.

Another reinforcement for the orientation of this subject is the meeting of the subject with the homosexual community so that the subject feels he has a friend so that the subject's behavior is regarded as something natural. But with the increasing age of the subject and the demands of developmental tasks at the age of the subject, it creates a feeling of abnormality for the subject. The desire to get married from within and the existence of environmental factors which indirectly assessed by the subject did not approve of their orientation, making the subject have a great desire to change and behave normally, namely marrying women, having children, family, and living happily.

There are many conflicts that arise in the subject itself when he has a desire to change, namely the absence of feelings of love for the subject of women and the difficulty of the subject to break away from the pleasure he feels while living a life as homosexual and added to the fear of losing happiness if he marries a woman .

From the model stage of forming homosexual sexual orientation, the subject stage can be explained from Cass's model of homosexual identity formation (in Gottchalk, 2005), that is, in junior high school, the subject begins to realize the difference between himself and other men, subjects who have an interest in playing with women rather than men man and subject begin to have awareness that he has different feelings towards fellow men, but in sexual intercourse the subject has not dared to express what he feels to others. Then the subject experiences the stages of comparing himself with other people so that the subject once feels that he is different from others. This makes the subject unable to accept his condition and still does not dare to say about his situation to others. But on the one hand when the subject finds people who have the same sexual orientation in themselves, tolerance begins to emerge in the subject so that the subject begins to look for partners and come into direct contact with people who have homosexual sexual orientation as well. The next stage is acceptance but the subject who is still aware of his differences with men in general and his demands for marriage like most couples make the subject difficult to accept him. This makes the subject have the desire to change. This strong desire to change prevents the subject from reaching the stages of acceptance identity, identity pride, and identity synthesis.

\section{Conclusions}

Homosexuality is physical and emotional attraction to same-sex. Various experiences occur in someone who has a homosexual sexual orientation. Besides that not all people with homosexual sexual orientation can accept their condition and be able to express it to others. In addition to someone with the same sexual orientation, they have varied experiences but also have various types of homosexual orientation. One of them is someone with a homosexual orientation but who has a desire to change called ego homosexuality.

An egodistonic homosexuality is a terms for a homosexual person's desire to marry the opposite sex, who wantto change, and wantto be normal according to himself and others. The desires that are not easy, there are many dilemmas felt by one, and one of them is having the desire to get married, completing their very own developmental task, and wanting to make their parents happy but having difficulties to be in love with the opposite sex.

According to the results of this study, some of the experiences ad phenomenon of an ego distonichomosexuality, are firstly the starting event, and followed byestablishmentof early signs of 
the development homosexuality orientation. Environmental factors hold a great role in forging that sexual orientation, adoptingpoint of views about homosexuality, inner factors and external factor could raises the desire to change, the presence of fear, hope, awareness of the ones conditions, having the desire to get married, inner conflict, and other related factors.

\section{References}

American Psychological Association (APA). Lesbian, gay, Bisexual, \& Transgender Concern.

Creswell, J.W. 2003. Qualitative Inqury and Reseach Design. SAGE Publication, Inc. California.

Crooks, R., \& Baur, K. 2007. Our Sexuality. 11 th ed. California: Brooks/Cole.

Davidson, G.C., Neale, J.M., \& Kring, A.M. 2006. Psikologi Abnormal. Jakarta: PT. Rajagrafindo Persada.

Gamache, P. \& Lazear, K.J. 2009. Asset-Based Approaches For LGBTQI2-S. Reseach \& TC.

Gottachalk, lorene. 2005. Coping with stigma: coming out and living as lesbians and gay men in regional and rural areass in the context of problems of rural confidentiality and social exclusion. Bushneedssocialworkjournal. 1-33.

Hurlock, E. B. 2004. Psikologi Perkembangan. Suatu Pendekatan Sepanjang Rentang Kehidupan. Edisi Kelima. Jakarta: Penerbit Erlangga.

Kartono, K. (1989). Psikologi Abnormal dan Abnormalitas Seksual. Bandung: Mandar Maju.

Kertzner, R.M. 2001. The Adult Life Course and Homosexual Identity in Midlife Gay Men. Annual Revew of Sex Research, 12, 75-92.

Kendall \& Hammer. 1998. Abnormal Psychology Human Problems Understanding Second Edition. Boston: Houghton Mifflin Company.

Maning, J.T. 2000. Identitas, pernikahan, pengakuan. Cerit, Kekuatiran dan harap hati kaum gay. Studi lapangan ACICIS (Australian Consotium for In Country Indonesia Studies).

McWhirter, D. P., Sanders A. S., \& Reinisch, M. J. 1990. Homosexuality/Heterosexuality, Concept of Sexual Orientation. New York: Oxford University Press.

Moustakas, Clark. 1994. Phenomenological Rsearch Methods. SAGE Publication, Inc. California.

Oetomo, D. 2003. Memberi suara pada yang bisu. Yogyakarta:Pustaka Marwa

Papalia, D. E., Olds, S. W., \& Feldman, R. D. 2009. Human Development, Nine Edition. New York : The McGraw-Hill Companies.

Perrin, E. C. 2002. Sexual Orientation in Child and Adolescent Health Care. New York: Kluwer Academic Publishers.

Poerwandari, E. K. 2007. Pendekatan Kualitatif untuk Penelitian Perilaku Manusia. Jakarta: Lembaga Pengembangan Sarana Pengukuran danPendidikan Psikologi UI.

Santrock, J. W. 2002. Life-Span Development. Edisi Kelima. Perkembangan Masa Hidup. Jilid II. Jakarta: Penerbit Erlangga. 